\title{
CHALLENGING STRATEGIC TRENDS IN GREEN SUPPLY CHAIN MANAGEMENT
}

\author{
Shahzad Ashraf ${ }^{* 1}$, Sehrish Saleem ${ }^{2}$, Abid H. Chohan ${ }^{3}$, Zeeshan Aslam ${ }^{4}$, Asif Raza ${ }^{5}$ \\ ${ }^{1}$ College of Internet of Things Engineering, Hohai University Changzhou Jiangsu China \\ ${ }^{2}$ Muhammad Nawaz Sharif University of Engineering \& Technology Multan Pakistan \\ ${ }^{3} \mathrm{NFC}$ Institute of Engineering \& Technology Multan Pakistan \\ ${ }^{4}$ Petroweld Oilfield Services Kurdistan, Iraq \\ ${ }^{5}$ Department of Automation, Shanghai Jiao Tong University, Shanghai, China \\ Corresponding Author: Shahzad Ashraf :Email: \{nfc.iet@hotmail.com\}
}

\begin{abstract}
The numerous environmental factors hindering the sustainable supply chain management have been taken into account. There is great need to examine the environmental and organizational impact to the green supply chain management. The researcher considers environmental sustainability strategies within companies, efficient supply chain management strategies for manufacturers and consumers, and environmentally friendly product and service design, taking a case-by-case perspective and concentrating on four large businesses. Our overall finding in the due course affirms that firms that leverage the green supply chain management are delivering greater environmental efficient output at an added cost. In future, such sagacious green policies have greater customer services which eventually create opportunities for suppliers, manufacturers and officials.
\end{abstract}

Keywords: Green supply chain, performance, operational management, development trends

\section{INTRODUCTION}

The principles relating to Supply Chain Environmental Management (SCEM) or Green Supply Chain Management (GSCM) are commonly understood by industry as tracking suppliers' environmental performance. However, conscious trade activities have been gaining growing consideration. In their policy designs an increasing number of businesses are pondering on the amalgamation of ecological practices [1]. In order to become more environment friendly, the businesses are given countless reasons. There are many factors that inspire the implementation and applications of the GSCM concept [2], such as demand forecasts, export performance, regulatory enforcement, and risk management. GSCM has a major role to play in verifying all of the aforementioned elements. The environmental impact will occur at all stages of the supply chain and the lifespan of a product, and GSCM emerges as a major new strategy for businesses to achieve a reduction in their ecological impact [3].

\section{RELATED FINDINGS}

An empirical review by American purchasing society on green purchasing found that compliance with the regulations is the fundamental motivating factor in green purchasing. It is predicted that the impact of environmental regulations on purchasing activities will become the second biggest issue in the future [4]. Although the relation between GSCM and the success of the companies was examined, the results were not conclusive. There are two opposite theories concerning the relation between performance and the effect on the environment. The first argues that environmental management should only ensure compliance with the legislation and the second suggests that environmental management should be able to raise costs and expenditures in order to produce better performance [5]. The effect of environmental parameters on investment in the use of electricity concluded that they related to the decline in industrial production. An optimistic link between the performance of a firm and environmentally friendly practices was reported. The suggested structure and empirical findings indicate a positive effect on market share and cost from ecological practices. Recent work has provided an overview of the future nature of supply chain activities to enhance the efficiency in an environmentally sustainable proceeding. Smaller and more regional businesses have been found easier to adopt more environmentally sustainable approaches [6]. Connecting with owners promotes the adoption and development of innovative environmental technologies, while working with customers and staff and cooperative Research and Development (R\&D) leads to better results in climate. If GSCM contributes to a positive or negative economic outcome is unclear however. The real long-term economic effect is not easily measured by considering a single factor, such as productivity in the short run or sales performance. The impact of companies on the environment faces increased cost of production but is also projected to slowly gain an increased market share. [7].

Authors in [8], noted that environmental management is in essence an innovative environmental design for institutional efficiency enhancements. It has been reported that an ecoefficient approach to the administration is capable of improving the functional efficiency of a firm. A clear connection has been identified between target meetings and 
the contribution of staff to environmental administration. The cost returns will be positively affected if consumers choose environment friendly business products / services, thereby expenditure can be reduced by diligent management of environmental criteria that can trigger hurdles. Furthermore, eco-friendly strategies can lead to developments that can provide businesses with a head-start advantage, at least from a marketing point of view. A positive relation between community, business performance and benefit has also been documented. Nevertheless, empirical studies about GSCM practices should be listed as scarce [9]. The questions set out during findings are: $i$ ) what are the effects of the green supply chain on firms' environmental and functional efficiency, and ii) what kinds of environmental management activities are recommended to boost the companies eco-efficient efficiency. The study framework is designed to explore the connection between the various GSCM practices. In the literature, there is agreement that eco-friendly activities are a crucial factor in increasing the success of a firm. Previous research illustrated multiple GSCM measurements listed in Table 1.

It has also been observed that GSCM can deliver many the solid and liquid waste, for using environment friendly logistics. Consequently, the Return on Investment (ROI) is considered a key aspect of GSCM [11].

\section{FINDING SCENARIOS}

Public data covering four large organizations GSCM activities are known as case studies. Firms are chosen on the basis of their market share, overall position, quality of data and overall environmental policy. Major firms have been chosen such that the principles and practices mentioned can be used as a potential pattern guide for smaller firms and policy makers.

\section{A. Eastman Chemical Company}

Eastman focuses on sustainable supply chain management methods and practical presentation improvement activities such as evaluating broker contributions, designing supplier substitution approaches, designing broker solutions [12]. improving packaging, using recyclable packaging and promoting supply chain networking, as well as developing consumer solutions and managing material recovery. Eastman

Table 1. Effective environmental Trends

\begin{tabular}{|c|c|c|c|c|}
\hline $\begin{array}{l}\text { Environmental } \\
\text { management trends }\end{array}$ & $\begin{array}{l}\text { Trends of GSCM for } \\
\text { suppliers and } \\
\text { consumers }\end{array}$ & $\begin{array}{l}\text { Environmentally } \\
\text { oriented quality and } \\
\text { service architecture }\end{array}$ & System quality & $\begin{array}{l}\text { Operational } \\
\text { quality }\end{array}$ \\
\hline $\begin{array}{l}\text { GSCM commitment } \\
\text { from senior and middle- } \\
\text { level executives }\end{array}$ & $\begin{array}{l}\text { Sustainable } \\
\text { collaboration with } \\
\text { manufacturers }\end{array}$ & $\begin{array}{l}\text { Environmentally safe raw } \\
\text { ingredients }\end{array}$ & $\begin{array}{l}\text { Solid / liquid waste and } \\
\text { emissions control }\end{array}$ & $\begin{array}{l}\text { Price savings and } \\
\text { productivity boost }\end{array}$ \\
\hline $\begin{array}{l}\text { Maximum resource } \\
\text { sustainability control }\end{array}$ & $\begin{array}{l}\text { ISO } 14000 \text { approval of } \\
\text { the manufacturer }\end{array}$ & $\begin{array}{l}\text { Development of goods } \\
\text { with decreased content and } \\
\text { energy usage }\end{array}$ & $\begin{array}{l}\text { Reduction of hazardous / } \\
\text { toxic material intake }\end{array}$ & $\begin{array}{l}\text { Improved product } \\
\text { consistency }\end{array}$ \\
\hline $\begin{array}{l}\text { Green policy and } \\
\text { inspection Program }\end{array}$ & $\begin{array}{l}\text { Company-wide } \\
\text { assessments of the } \\
\text { workplace }\end{array}$ & $\begin{array}{l}\text { Material construction for } \\
\text { reuse, recycling and } \\
\text { content recovery }\end{array}$ & $\begin{array}{l}\text { Minimization of } \\
\text { environmental incident } \\
\text { incidence }\end{array}$ & $\begin{array}{l}\text { Different prospects } \\
\text { for the sector }\end{array}$ \\
\hline Excepting trends & $\begin{array}{l}\text { Corporate regulation } \\
\text { for local vendors }\end{array}$ & $\begin{array}{l}\text { Material construction to } \\
\text { prevent or reduce the use } \\
\text { and/or production of } \\
\text { dangerous goods }\end{array}$ & $\begin{array}{l}\text { Electricity consumption } \\
\text { loss }\end{array}$ & $\begin{array}{l}\text { Enhance the morale } \\
\text { and efficiency of } \\
\text { workers }\end{array}$ \\
\hline
\end{tabular}

advantages from cost savings to increased public participation (i.e. establishing a trend) in the company's strategy and, ultimately, increased market share. Therefore, environmental issues are becoming a clear component in corporate tactical patterns. Green ads and environment friendly packages are activities which could boost the supply chain environmental impact. To highlight the environmental impact of packaging, some countries have programs aimed at minimizing wrapping costs. It has been stated that standardized recyclable containers and fine merchandising designs reduce the availability and turnaround time, rendering the product costeffectively [10]. The eco-efficient manufacturing of warnings and procedures may combine many such concepts, from the use of materials and resources during the early stages of the supply chain, that introduce the sustainable practices to reduce implements many environmental quantifiers and by incorporating a greenhouse mitigation target, called TRI (Toxic Release Inventory) [13], has established the ecoefficient task practices. The design of Eastmans energy management strategy has balanced demand for fair energy consumption with demand to minimize cost of production, for example by ensuring that the heat generated is used in more than one chemical process. The organization also claims to use effective water management methods and recyclable materials to the wastage [14].

\section{B. Westpac Bank, Australia}

The fundamental advantage of this business is that it partners with distributors and consumers in order to improve its production and goods, e.g. by redesigning the packaging and using recyclable materials in a variety of items. That process 
has brought changes in quality and decreased logistical costs [15]. The organization has announced a commitment to comply with, or even meet, the requirements of environmental legislation in the areas it operates. The firm claims that, although it is a certified Carbon Neutral company, it has ensured reduced energy consumption and emissions in transport [16].

\section{Coca Cola Enterprises}

The corporation endorses the Common Reporting Standard (CRS) [17], tension aspects of five strategic business obligations and sustainability. In 2008, Coca Cola spent US\$ 34.8 million in capital schemes relating to its three ecoefficient spotlights [18]. In addition, they are creating a costfriendly evaluation method to report on investments under the CRS. In the area of energy usage, water conservation, sustainable wrapping manufacture variety, well-being and diverse and inclusive community, the firm have highlighted these objectives. Compared to the 2007 reference, it has decreased the entire carbon level to 15 per cent in 2020 [19]. The organization also pursues a water-sustainable role in which water usage is minimized and water-neutral efficiency achieved. The use of recyclable resources has been set as a major target to reduce the impact of packaging-related waste. The organization evaluated and claims to have decreased its carbon marks by the use of a hybrid fleet, creating a watersustainable role, thereby decreasing the water consumption ratio and saving more than 300 million liters of water, thus undertaking a pilot study of enclosed stream footprint [20]. In order to minimize the impact of packaging materials, the organization has stayed away from the use of some 31,000 metric tons of packaging materials, although $2.7 \%$ of the total quantity has been recovered.

\section{Ernst and Young}

The company has adopted the Sustainability Assessment Approach and is a member of the Green Finance Committee of the China Financial Institution. The facilities offered are environmentally sustainable and comply with international standards and regulations [21]. The business specializes in providing its clients with customized environmental programs such as carbon mitigation consulting and financing, management of the supply chain, compliance etc.

\section{DISCUSSION}

It is enough to claim that carbon emissions are to be considered as currency in the coming days. Therefore, steps to monitor its supply chain and the calculation of potential costs and liabilities is critical for international companies. About $40 \%$ of companies have invested in renewable energy production to combat energy inflation and rising domestic emissions, providing a firm grip on energy costs and strengthening firm reputation and could even become profitable when selling the surplus electricity generated. In order to increase their market share, rising traders are battling the launch of sustainable production. Sustainability is an opportunity for sales growth in a significant number of participants. Several leading companies must assess in the sustainable chain management account the full prospective and future advantages and profits. If the supply chain is found to be communally insensitive, the credibility of a corporation is at risk. Environment friendly and sustainable activities on the other hand boost a company's image and eventually, even with higher cost goods and its market shares [22].

Global businesses devote substantial resources to positive environmental effects, to the production and development of new technologies and solutions, to energy efficiency, packaging enhancement, use of recycled materials etc. Other minor activity such as greenhouse excretion reduction and logistics efficiency protection were also recorded in addition to prominent eco-friendly activities. Additional benefits often obtained including improved performance, lower costs, enhanced risk reduction, income growth, and a reliable reputation. An ethical supply chain is more critical for a business. Enhanced risk management and reputation are the practical component to be incorporated into the current framework. Companies that use Sustainable Supply Chain Management (SSCM) [23], activities have major environmental and functional impacts. Such work was constrained by the ease of sampling, so that more detailed case studies could be performed.

\section{CONCLUSION}

This research was carried out to examine the practical, as well interact the social relationship of SSCM practice in the businesses. A juncture has been set up and attempts have been made in case studies to verify the structure. In particular, the implementation of sustainable policies and the functional performance of organizations in the supply chain administration were evaluated. The research is intended to help incorporate environmental or ecological management of the supply chain to improve productivity on the world market. The biggest environmental challenge is the reduction in carbon emissions. The foremost objective of this study was to analyze and take a path to tackle the ecological aspects of supply chain management.

\section{REFERENCES}

[1] N. P. Archer, "Supply chains and the enterprise," J. Enterp. Inf. Manag., vol. 19, no. 3, pp. 241-245, May 2006, doi: 10.1108/17410390610658432.

[2] S. Ashraf, T. Ahmed, S. Saleem, and Z. Aslam, "Diverging Mysterious in Green Supply Chain Management," Orient. J. Comput. Sci. Technol., vol. 13, no. 1, pp. 22-28, May 2020, doi: 10.13005/ojcst13.01.02.

[3] Y.-F. Wang, S.-P. Chen, Y.-C. Lee, and C.-T. (Simon) Tsai, "Developing green management standards for restaurants: An application of green supply chain management," Int. J. Hosp. Manag., vol. 34, pp. 263-273, Sep. 2013, doi: 10.1016/j.ijhm.2013.04.001.

[4] S. Ashraf, Z. A. Arfeen, M. A. Khan, and T. Ahmed, "SLMOJ: Surrogate Learning Mechanism during Outbreak 
Juncture," Int. J. Mod. Trends Sci. Technol., vol. 6, no. 5, pp. 162-167, May 2020, doi: 10.46501/IJMTST060525.

[5] S. Ashraf, S. Saleem, T. Ahmed, and M. A. Khan, "Multibiometric Sustainable approach for human Appellative," Trends Comput Sci Inf Technol, vol. 5, no. 1, pp. 001-007.

[6] M.-L. Tseng, M. S. Islam, N. Karia, F. A. Fauzi, and S. Afrin, "A literature review on green supply chain management: Trends and future challenges," Resour. Conserv. Recycl., vol. 141, pp. 145-162, Feb. 2019, doi: 10.1016/j.resconrec.2018.10.009.

[7] S. Ashraf, T. Ahmed, A. Raza, and H. Naeem, "Design of Shrewd Underwater Routing Synergy Using Porous Energy Shells," Smart Cities, vol. 3, no. 1, pp. 74-92, Feb. 2020, doi: 10.3390/smartcities3010005.

[8] S. Luthra, V. Kumar, S. Kumar, and A. Haleem, "Barriers to implement green supply chain management in automobile industry using interpretive structural modeling technique: An Indian perspective," J. Ind. Eng. Manag., vol. 4, no. 2, pp. 231-257, Jul. 2011, doi: 10.3926/jiem.2011.v4n2.p231-257.

[9] M. A. Sellitto, J. Luchese, J. M. Bauer, G. G. Saueressig, and C. V. Viegas, "Ecodesign Practices in a Furniture Industrial Cluster of Southern Brazil: From Incipient Practices to Improvement," J. Environ. Assess. Policy Manag., vol. 19, no. 01, p. 1750001, Mar. 2017, doi: $10.1142 / \mathrm{S} 1464333217500016$

[10] S. Ashraf et al., "Underwater Routing Protocols Analysis of Intrepid Link Selection Mechanism, Challenges and Strategies," Int. J. Sci. Res. Comput. Sci. Eng., vol. 8, no. 2, pp. 1-9, Apr. 2020, doi: 10.26438/ijsrcse/v8i2.19.

[11] R. M. Grant, "Prospering in Dynamically-Competitive Environments: Organizational Capability as Knowledge Integration," Organ. Sci., vol. 7, no. 4, pp. 375-387, Aug. 1996, doi: 10.1287/orsc.7.4.375.

[12] "Eastman | The results of insight." https://www.eastman.com/Pages/Home.aspx (accessed Jun. $05,2020)$.
[13] "Toxics Release Inventory - What is it?," Earthworks. https://earthworks.org/issues/toxics_release_inventory_what is_it/ (accessed Jun. 07, 2020).

[14] S. Ashraf, M. Gao, Z. Chen, S. Kamran, and Z. Raza, "Efficient Node Monitoring Mechanism in WSN using Contikimac Protocol," Int. J. Adv. Comput. Sci. Appl., vol. 8, no. 11, 2017, doi: 10.14569/IJACSA.2017.081152.

[15] "Westpac Group." https://www.westpac.com.au/aboutwestpac/westpac-group/ (accessed Jun. 05, 2020).

[16] S. Ashraf, M. Gao, Z. Mingchen, T. Ahmed, A. Raza, and H. Naeem, "USPF: Underwater Shrewd Packet Flooding Mechanism through Surrogate Holding Time," Wirel. Commun. Mob. Comput., vol. 2020, pp. 1-12, Mar. 2020, doi: $10.1155 / 2020 / 9625974$.

[17] "Common Reporting Standard (CRS) - Organisation for Economic Co-operation and Development." https://www.oecd.org/tax/automatic-exchange/commonreporting-standard/ (accessed Jun. 07, 2020).

[18] "The oca-Cola Company: Refresh the World. Make a Differene." https://www.coca-colacompany.com/ (accessed Jun. 05, 2020).

[19] S. Ashraf, S. Saleem, and T. Ahmed, "Sagacious Communication Link Selection Mechanism for Underwater Wireless Sensors Network," Int. J. Wirel. Microw. Technol., vol. 10, no. 2, pp. 12-25.

[20] S. Ashraf, A. Raza, Z. Aslam, H. Naeem, and T. Ahmed, "Underwater Resurrection Routing Synergy using Astucious Energy Pods," J. Robot. Control JRC, vol. 1, no. 5, 2020, doi: 10.18196/jrc. 1535 .

[21] "Who we are - Builders of a better working world | EY Global." https://www.ey.com/en us/who-we-are (accessed Jun. 05, 2020).

[22] S. Ashraf, A. Yahya, and M. A. Khan, "Culminate coverage for sensor network through Bodacious-instance Mechanism," -Manag. J. Wirel. Commun. Netw., vol. 8, no. 3, pp. 1-7.

[23] "The Sustainable Supply Chain." https://hbr.org/2010/10/thesustainable-supply-chain (accessed Jun. 07, 2020). 